\title{
Energy benefits of integrating transportation energy with a net zero energy solar building using captured waste hydrogen from electrochemical plants and biogas from various bio gasification processes
}

\author{
Shahryar Garmsiri, Marc A. Rosen \\ Faculty of Engineering and Applied Science \\ University of Ontario Institute of Technology \\ Oshawa, Ontario, Canada
}

\begin{abstract}
When considering a net zero energy building, the transportation energy sector is often viewed as a separate entity. Currently, hydrocarbons are the main source of energy used in the transportation sector. In an effort to reduce greenhouse gas emissions, more automotive manufacturers are moving towards alternatively fueled vehicles that are electric or fuel cell powered. Electrochemical and other process industries frequently vent or flare hydrogen into the atmosphere and most community municipal waste is buried underground (landfill) or burned to generate electricity resulting in greenhouse gas emissions. Energy benefits and the methods of achieving net zero energy status for a solar building and reduction of greenhouse gas emissions through the integration of these waste streams and transportation energy are discussed.
\end{abstract}

Keywords- Waste hydrogen, biogas, biodigestion, chlor-alkali, fuel cell, transportation energy integration, net zero energy building, building integrated photovoltaic/thermal, waste energy recovery

\section{INTRODUCTION}

Hydrocarbon fuels that are responsible for a relatively large proportion of the overall greenhouse gas (GHG) emissions are the main source of energy used in the transportation sector. An overview of 2015 reported emissions by sector was published in 2017 by Environment and Climate Change Canada [1]. Emissions reported in 2014 by sector in the City of Toronto [2] indicate that the transportation sector contributes $35 \%$ of overall emissions while $53 \%$ of the overall emissions are produced by buildings. The City of Toronto has committed to reducing GHG emissions by $80 \%$ of 1990 levels by 2050, through increases of renewable and district power generation [2]. To this end the City of Toronto has developed a zero emissions building framework, which targets building performance to near-zero emissions level by the year 2030 [2].

A net zero energy building (NZEB) is a building that offsets all of its energy consumption by using renewable energy sources within the building's built environment [3]. Most net zero energy buildings use the electrical grid as a buffer to avoid the need for energy storage. The building's energy demand is typically generated on-site through a

National Sciences and Engineering Research Council (NSERC) renewable energy source such as solar. A net zero energy building's performance is increased through efficiency measures and waste energy recovery so that the balance of energy needed within the building, both thermal and electrical, is usually met by the renewable source of energy. However, solar energy is intermittent due to weather conditions and the balance is not met through the renewable source of energy; hence the building relies on the electrical grid for the energy demand.

Climate change has become an important topic world-wide, as have reduction targets for GHG emissions. The transport sector is identified as one of the key sectors contributing to climate change $[4,5]$. Along with the growing gap between oil supply and demand globally, and the need to reduce GHG emissions, the use of alternative fuels and energy efficiency improvements are receiving increased attention [6].

In an effort to meet emission targets set out by each country, alternative methods of energy production must be considered such as solar power, wind energy, bio gasification, and waste energy recovery techniques. Although hydrogen energy technology has received much attention in the last decade with significant progress in performance, reliability, cost and efficiency, producing hydrogen from fossil fuels is not a clean, sustainable approach. There are also economic, intermittency and efficiency implications of hydrogen production from renewable energy sources. One method of addressing these implications is through the recovery of waste energy in a community.

Electrochemical and other process industries such as chloralkali plants frequently vent or flare hydrogen process gas into the atmosphere. The sodium chlorate used as a reactant for water purification and paper bleaching processes in a chloralkali plant produces hydrogen as a by-product. This waste hydrogen can be captured and purified for use in a hydrogen proton exchange membrane (PEM) fuel cell for transportation or stationary power generation.

A study of the economics of hydrogen production, storage and delivery was conducted by International Energy Agency (IEA) [7] for transportation use. The environmental benefits were outlined, with key points demonstrating the potential benefits of renewable hydrogen production, and utilization for 
various modes of transportation. The Integrated Waste Hydrogen Utilization Project (IWHUP), the world's first wastehydrogen capture system for fuel cell applications, was installed at a chemical plant in North Vancouver, British Columbia [8]. Additional waste-hydrogen capture systems are in development.

When considering a net zero energy building or community, the transportation energy sector is often viewed as independent from the building sector of the community. In this paper, the integration of transportation energy with a net zero energy building utilizing captured waste hydrogen from chloralkali plants and biogas from various bio gasification processes is examined.

Energy benefits and the methods of achieving net zero energy status for a solar building, and the reduction of greenhouse gas emissions through the integration of transportation energy are described. The objective of this paper is to demonstrate usable waste gas reduction and community waste energy recovery for use in the building and transportation sectors while utilizing a fuel cell vehicle's energy storage and production capabilities.

\section{BACKGROUND}

\section{A. Net zero energy building}

A net zero energy building (NZEB) is a building that offsets all of its energy consumption by using renewable energy sources within the building's built environment [3]. Net zero energy performance may be achieved by a combination of reducing building energy demand and generating electricity through the increased use of renewables, efficiency measures, waste energy recovery methods and integration of transportation energy.

Most net zero energy buildings use the electrical grid as a buffer to avoid the need for energy storage. The building's energy demand is typically generated on-site through a renewable energy source such as solar. Because solar energy remains intermittent due to the weather conditions, it may not be considered as a dependable source of energy to meet the building's energy demands.

\section{B. Solar energy}

In a photovoltaic (PV) module, a portion of the incident solar energy is converted into useful electricity, while the rest is either reflected or dissipated as heat. There are two methods of installing PV modules on a building. A building added photovoltaic (BAPV) system has the PV modules installed as an addition to the building envelope. A building integrated photovoltaic (BIPV) system has the PV modules forming part of the building installation. When adding a heat recovery system for module cooling purposes and to capture generated waste heat by the BIPV solar module, the system is referred to as a building integrated photovoltaic/thermal (BIPV/T) system. The BIPV/T system not only generates electricity, but also provides useful heat that allows for a reduction in the building heating loads $[9,10]$.

\section{Electrochemical chlor-alkali industry plants}

In a chlor-alkali facility, chlorine $\left(\mathrm{Cl}_{2}\right)$ and sodium hydroxide $(\mathrm{NaOH})$ are manufactured by electrolysis of brine, a salt solution [11]. The main technologies applied for chloralkali production are mercury cell, diaphragm and membrane cell electrolysis, mainly using sodium chloride $(\mathrm{NaCl})$ as feed [11]. Each of these processes represents a different method of keeping the chlorine that is produced at the anode separate from the caustic soda and hydrogen that are produced at the cathode.

The inputs are primarily salt and water; acids and chemical precipitants are used to remove impurities and output chlorine and caustic solution [11]. The main pollutant outputs are chlorine gas emissions to air, free oxidants to water, spent acids, cooling agents, and impurities removed from the input brine salt and hydrogen gas.

\section{Waste hydrogen gas}

The chlor-alkali industry produces chlorine and caustic solution (sodium or potassium hydroxide) simultaneously through decomposition of salt in water. The basic principle in the electrolysis of a sodium chloride solution occurs at the anode and cathode. At the anode, chloride ions are oxidized and chlorine $\left(\mathrm{Cl}_{2}\right)$ is formed. At the cathode, hydrogen $\left(\mathrm{H}_{2}\right)$ and hydroxide ions $\left(\mathrm{OH}^{-}\right)$are formed by the reaction of the sodium in the amalgam with water.

During chlorine gas compression and cooling, most of the chlorine gas is condensed. However, by diluting the remaining chlorine gas with air, the concentration of non-condensable gases such as hydrogen can be kept below the explosion limit. The remaining gases after liquefaction have to be purged from the system and are led to a chlorine absorption unit. The remaining impurities in the gases in the chlorine absorption unit is absorbed and the remaining gas is $97.5-99.9 \%$ pure hydrogen [12].

This pure hydrogen gas can be used in hydrogen proton exchange membrane (PEM) fuel cells for stationary or vehicle use applications. Often times the gas is either sold to merchants or vent/flared into the atmosphere. In this study, the focus is made on the vent/flared hydrogen gas into the atmosphere.

In a chlor-alkali electrochemical plant, hydrogen is produced in a fixed ratio of $28 \mathrm{~kg}$ per tonne of chlorine used or approximately $1200 \mathrm{~kg}$ per day ranging up to approximately $2700 \mathrm{~kg}$ per day [11].

\section{E. Biogasification processes}

There are a variety of ways to use wastes and to convert them into useful energy. Some of these include gasification processes that uses wood or coal, and anaerobic digesters that use biodegradable material such as municipal solid waste and sewage sludge to create a biogas that is useful for combustion to generate power. This useful gas can be further processed and converted to hydrogen to be used in fuel cells.

Gasification is a process of converting organic materials into carbon monoxide $(\mathrm{CO})$, hydrogen $\left(\mathrm{H}_{2}\right)$, and carbon dioxide $\left(\mathrm{CO}_{2}\right)$. The process involves burning of solid fuels like wood or coal to complete combustion with inadequate air supply, 
creating an output gas called synthesis gas with potential for combustion. The power produced from gasification and combustion of the synthesis gas obtained from biomass is considered to be a source of renewable energy $[13,14,15,16]$. This synthesis gas can further be processed in a steam reformer for subsequent conversion to hydrogen.

Some examples of demonstration projects include the 20 MW synthesis gas from forest residues by GoBiGas project in Gothenburg, Sweden [18], a 2 MW electricity production facility in Gussing, Austria by the Renewable Energy Network Austria (RENA) [19] and the US Air Force in Hurlburt Field, Florida [17].

\section{F. Integration of transportation and renewable sources of energy}

Several studies concerning the possibilities of integrating renewable sources of energy with the transportation sector have been pursued. Some of these studies include electricity produced by wind turbines in combination to plug-in hybrid vehicles (PHEVs) [20], leading to the potential of using electric vehicle battery storage as a medium for excess energy produced by wind power [21]. Similarly, solar photovoltaic (PV) systems have received attention in tandem with electric vehicles (EVs). A study conducted in Germany [22] demonstrated the potential of $\mathrm{CO}_{2}$ emissions reduction in the transportation sector when using EV's paired with solar PV's.

The method of integrating transportation energy with a building is referred to as vehicle-2-grid (V2G) [23,24]. Although most of the research is based on EVs, attention is required for fuel cell vehicles (FCV) as well. A FCV can generate power using its onboard stored hydrogen as compared to an EV that can be seen simply as a storage medium that cannot produce electricity. An advantage to a FCV over an EV is the potential of storing a greater amount of energy in compressed gas form and generating electricity using the onboard fuel cell. FCVs can also be refueled much faster than EVs.

There are several benefits when integrating transportation energy to achieve a net zero energy balance for a building. The integration using a FCV helps to eliminate the need for centralized large power generators, and provides a vector for the utilization of industrial waste hydrogen gas, synthesis gas and biogas from gasification and anaerobic digester processes converted to hydrogen during a steam reformation process.

\section{G. Fuel cell systems}

There are several types of fuel cells that can be used for stationary and vehicle applications. The proton exchange membrane fuel cell (PEMFC) capitalizes on the essential simplicity of the fuel cell. Most biogases have low heating values, due to the high levels of carbon oxides and nitrogen, which are not attractive for gas engines. The molten carbonate fuel cell (MCFC), solid oxide fuel cell (SOFC), and phosphoric acid fuel cell (PAFC) are able to handle very high concentrations of carbon oxides [25].

Although there are several fuel cell types that can be used for creating electrical power, the PEM fuel cell is considered more advantageous than MCFC, SOFC and PAFC types. This is due to the limitations MCFC, SOFC and PAFC have over the PEMFC. The limitations are that MCFC, SOFC and PAFC operate at higher temperatures and are not ideal for stop and go applications. But a PEMFC is not limited to the high operating temperatures and has the capability of stop and go operation, making it an advantageous fuel cell for vehicle application [25].

\section{ANALYSIS AND METHODOLOGY}

Modelling community and transportation energy use can present several challenges, such as acquiring and generating appropriate input data based on highly variable energy usage patterns. How and when occupants exercise their energy needs is a key consideration for all green building planning, design, operations and decision-making.

Fuel cell vehicles can be used as a new power generation source, supplying electricity to homes, and to the grid. The V2G mode helps implement this connection and uses the hydrogen fuel cell powertrain and the stored hydrogen on board the vehicle as a new power generation source supplying electricity.

\section{A. House electrical consupmtion}

A bungalow style house is chosen for this study, however the model can be applied to any size and type of house. It is assumed that all the appliances in the house are electrical including the domestic hot water tank. A list of common appliances and devices that use electricity are outlined in Table 1. 
TABLE I. ELECTRICAL APPLIANCES IN THE HOUSE

\begin{tabular}{|c|c|c|c|}
\hline \multirow{2}{*}{$\begin{array}{c}\text { Appliance and } \\
\text { Device }\end{array}$} & \multicolumn{3}{|c|}{ Description } \\
\hline & Spot measurement $(W)$ & Model & COP \\
\hline Electric furnace & 4,600 & NT14A018A & 0.83 \\
\hline Air conditioner & 10,000 & 21ECM10 & 1.00 \\
\hline $\begin{array}{l}\text { Electric domestic } \\
\text { hot water }\end{array}$ & 3,500 & RTEX-04 & \\
\hline Fridge & 57.20 & $\begin{array}{c}\text { LG } \\
\text { LTCS24223 }\end{array}$ & \\
\hline Clothes washer & 13.70 & $\begin{array}{c}\text { LG } \\
\text { WM9500H* } \\
\text { A }\end{array}$ & \\
\hline Clothes dryer & 7,200 & $\begin{array}{c}\text { DLEX7600 } \\
\text { VE }\end{array}$ & \\
\hline LED television & 70 & LGUH6100 & \\
\hline Electric stove & 3,800 & $\begin{array}{c}\text { YWEE510S } \\
\text { OFS }\end{array}$ & \\
\hline Dishwasher & 27.30 & $\begin{array}{c}\text { Samsung } \\
\text { DW80K704 } \\
9 \\
\end{array}$ & \\
\hline Microwave & $2.20-10$ & & \\
\hline $\begin{array}{l}\text { Lighting (Candle } \\
\text { light, A19, T8, } \\
\text { MR16, PAR30) }\end{array}$ & $5,10,18,5,14$ & LED & \\
\hline Coffee maker & $70-1,000$ & & \\
\hline $\mathrm{PC}$ and monitor & $6.4-75$ & & \\
\hline Laptop & $2-25$ & & \\
\hline Stereo & 30 & & \\
\hline DVD player & $3.8-17$ & & \\
\hline $\begin{array}{ll}\text { Video } & \text { game } \\
\text { consoles } & \\
\end{array}$ & $3.6-36$ & & \\
\hline Chargers & $4-13$ & & \\
\hline $\begin{array}{l}\text { All in one printer } \\
\text { and scanner }\end{array}$ & 4.40 & & \\
\hline Router & 8 & & \\
\hline Phone & 2.80 & & \\
\hline
\end{tabular}

The heating and cooling electrical consumption from the electric heater and air conditioner used for this house depends on the wall insulation and the assumption of steady state heat loss and heat gain in the house. The heat loss and heat gain for the house is calculated as follows:

$$
\text { Q }=\square A \Delta T
$$

where $\mathrm{Q}$ is the heat loss during winter and heat gain during summer, $U$ is the measure of the effectiveness of the total insulation, $\mathrm{A}$ is the area of the house, and $\Delta \mathrm{T}$ is the outside air and house internal temperature. The comfortable indoor air temperature for winter according to a study is between $20^{\circ} \mathrm{C}$ and $23^{\circ} \mathrm{C}$ [26], while the comfortable indoor air temperature for summer is between $23^{\circ} \mathrm{C}$ and $25^{\circ} \mathrm{C}$ [26].
The effectiveness of the insulation of the house is calculated using the R-value of the insulating materials. The $\mathrm{R}$ value is the capacity of an insulating material that resists heat flow, and the higher the R-value, the greater the insulation for the application.

The $U_{\text {total }}$ the measure of the effectiveness of an insulator for the house, is calculated from the total $U$ values of the windows, doors, walls, floors, ceiling, and roof that comprises of the components of a house. The lower the $\mathrm{U}$ value, the better the material for heat insulation. The $\mathrm{U}_{\text {total }}$ can be calculated as follows:

$$
\bigcup_{\text {total }}=\bigsqcup_{\text {window }}+\bigsqcup_{\text {door }}+\bigsqcup_{\text {wall }}+\bigsqcup_{\text {floor }}+\bigsqcup_{\text {ceiling }}+\bigsqcup_{\text {roof }}
$$

The electric consumption of the electric heater and air conditioner is calculated for each hour of the year. Similarly the electrical usage of appliances, lighting apparatuses and other appliances in the house are quantified as follows:

$$
E_{\text {House_total }}=E_{\text {Appliances }}+E_{\text {lighting }}+E_{\text {Devices }}
$$

where $\mathrm{E}_{\text {appliances }}$ is the total electricity used by the appliances for the duration of an hour, $E_{\text {lighting }}$ is the total electricity used by the lights in the house for an hour, and $E_{\text {Devices }}$ is the total electricity used by devices in the house that use electricity for an hour. The appliances, lighting and devices used for this study are listed in Table 1.

\section{B. Solar power generation}

The number of solar panels that can be installed onto the rooftop of the house can be written as:

$$
\mathrm{Npv}=\left(\mathrm{A}_{\mathrm{rou}} / 4\right)^{*}(1 / \mathrm{Apv})
$$

where $\mathrm{N}_{\mathrm{PV}}$ is the number of solar panels, $\mathrm{A}_{\text {roof }}$ is the area of the roof and APV is the area of the solar panel. The solar array area can be calculated as:

$$
A_{\text {array }}=A_{p v}{ }^{*} \mathrm{Npv}
$$

The maximum power capacity of the total solar PVs installed on the rooftop can be calculated as follows:

$$
\mathrm{PV} \text { total }=\text { Aarray }^{*} \eta_{\text {module }}
$$

where $\eta_{\text {module }}$ is the solar module efficiency.

By varying the area of the roof and calculating the maximum power capacity, the total solar PVs can also vary and this is can be used for various house sizes. Using the information calculated the electricity produced per hour (EPV) can be obtained from the NREL website [27].

\section{Fuel cell vehicle fuel usage}

There are several examples of development of hydrogen vehicles in the past decade. The automotive sector is a good 
candidate for using hydrogen to reduce $\mathrm{CO}_{2}$ emissions, as the quantity of vehicles exceeds the numbers of other modes of transportation. On board hydrogen storage is in the range of approximately 5 to $13 \mathrm{~kg}$, a requirement to enable a driving range of more than $480 \mathrm{~km}$ (300 miles) for the full platform of light-duty automotive vehicles using fuel cells [28].

The fuel cell hydrogen usage can be made comparable to the house electricity usage and the solar panel power generation by using (7) to convert $1 \mathrm{~kg}$ of hydrogen to $\mathrm{kWh}$.

$$
33.22 \mathrm{kWh} / \mathrm{I} \mathrm{kghydrogen}{ }^{*} \eta \text { PeM fuel cell }=\text { Ehydrogen }
$$

where the PEM fuel cell efficiency is assumed to be $60 \%$ and $\mathrm{E}_{\text {hydrogen }}$ is the useable $\mathrm{kWh}$ per $\mathrm{kg}$ of hydrogen. Equation (8) can be used to determine the $\mathrm{kWh}$ of energy on board a fuel cell vehicle:

$$
\text { Ehydragen } * \text { Shydrogen storage }=\text { EFCV }
$$

where $S_{\text {hydrogen storage }}$ is the fuel tank size in $\mathrm{kg}$, and $\mathrm{E}_{\mathrm{FCV}}$ is the amount of energy on board measured in $\mathrm{kWh}$.

The electricity usage rate per kilometer is based on an assumption of combined city and highway driving. In this study it is assumed that the driving distance is constant with no road traffic or diversions of the path traveled between the workplace and the house.

\section{RESULTS AND DISCUSSION}

The data for the electrical consumption of the house, the power generated by the solar PV and the hydrogen usage by the FCV (and hence the amount potentially available for building operations) can be determined on an hourly basis for the duration of a year.

In this case with the current solar panel installation, the sum of the electricity produced and the electricity used by the house makes this house a net negative energy building. The calculations show that a total of $17,650 \mathrm{kWh}$ of electricity is used from the grid annually as shown in Figure 1.

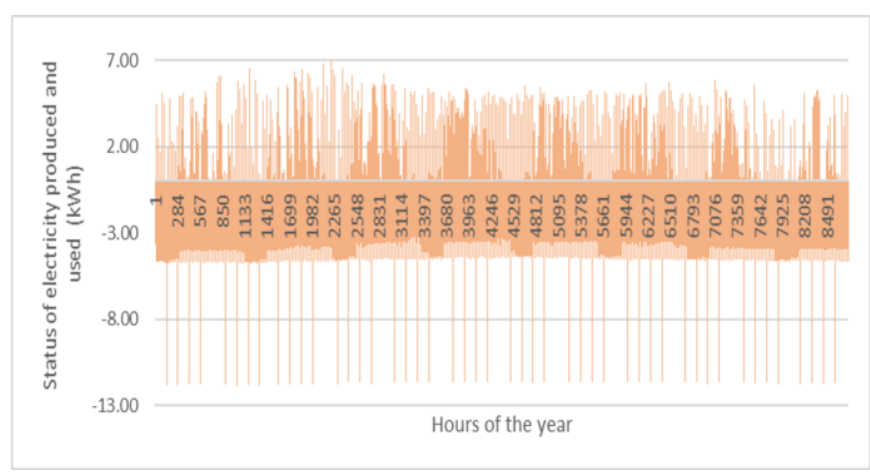

Figure 1. Total summed electricity produced by the solar PV and the electricity used by the house $(\mathrm{kWh})$

From this study it is observed that the electricity produced by the solar PV is not fully utilized during the day, while the occupants are away at work and most of the electricity consumption is during peak times when they have arrived back at the house from the workplace. To demonstrate this, day 1 is extracted from Figure 1 and shown in Figure 2 below.

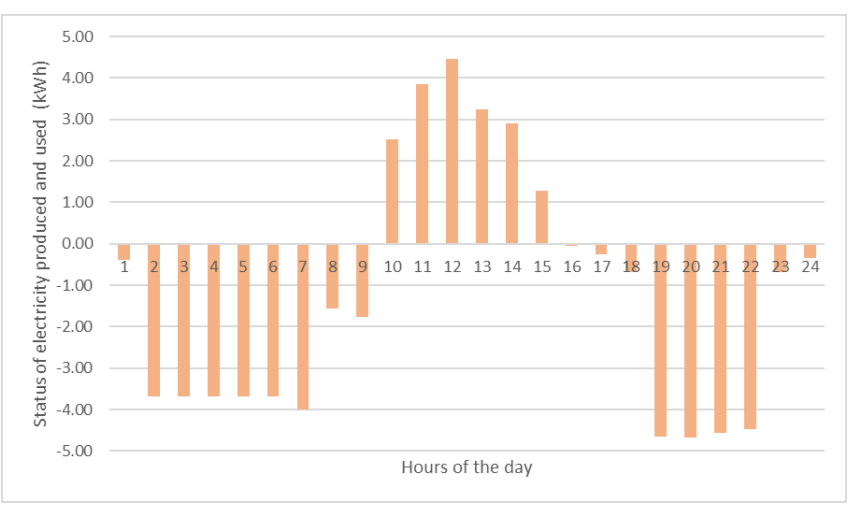

Figure 2. Sum of electricity produced and electricity used for Day $1(\mathrm{kWh})$

The FCV can be used to offset the net shortfall of the electricity produced by the solar PV throughout the day by using the hydrogen fuel cell on board the vehicle during high peak hours. The surplus electricity generated between 10am and $3 \mathrm{pm}$ is sent to the grid but is subsequently offset, during high peak times through the integration of FCV to the house. The integration of the FCV to the house for Day 1 can be observed in Figure 3, where the orange bar represents the sum of the electricity produced by the solar PV and the electricity used by the house compared to the green lines representing when electricity from the FCV was used. The house becomes a net positive energy building annually with $3,321 \mathrm{kWh}$ provided by the integration of FCV. This indicates that approximately $21,000 \mathrm{kWh}$ of solar PV energy that was not fully used by the house may be sent to the grid. The integration of the FCV powered by waste gas streams indicates that the house is fully powered from zero emission sources maintaining its net zero energy status.

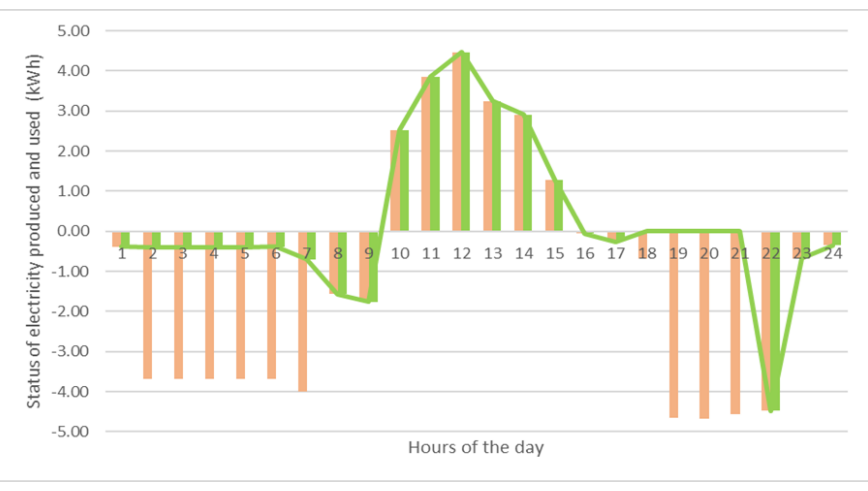

Figure 3. FCV integration to the zero energy building (kWh)

\section{CONCLUSIONS}

The integration of the FCV with a net zero energy building can be beneficial. This is due to the solar PV energy not being fully used by the unoccupied house during the day. The fuel recovered from the waste streams, such as hydrogen from electrochemical plants, synthesis gas converted to hydrogen 
using steam reformation from bio gasification and anaerobic digestion processes, is used by the FCVs. The FCV's power generation capability allows the house to remain fully powered from zero emission sources and to utilize waste streams from the community.

\section{REFERENCES}

[1] Environment and climate change Canada. Overview of 2015 reported emissions. Gatineau, Quebec. Available online: https://www.ec.gc.ca/ges-ghg/82BA1E22-9653-45F1-8EC29BF8A2151555/ECCC_GHGRP_OverviewOfReported2015Emissions.p df (accessed on 1 February, 2018)

[2] City planning division. The City of Toronto zero emissions building framework. Toronto, Ontario. Available online: https://web.toronto.ca/wp-content/uploads/2017/11/9875-Zero-

Emissions-Buildings-Framework-Report.pdf (accessed on 29 January, 2018)

[3] Pless, S. D., Torcellini, P.A., (2010). Zero Energy Buildings: A Classification System Based on Renewable Energy Supply Options, National Renewable Energy Laboratory, Golden, CO, Report NREL/TP$550-44586$

[4] Commission of Integrated Transport. Transport and climate change, advice to government from the commission for integrated transport. London: CFIT-Publications; 2007. Available online: http://www.cambridgeenergy.com/archive/ 2007-02-08/commissioninteg-trans.pdf (accessed on 5 January 2015).

[5] Stanley J, Loader C. Road transport and climate change: stepping off the greenhouse gas. Report for the bus industry confederation, Victoria. 2008. Available online: http://www. ozebus.com (accessed on 5 November 2014).

[6] Kumar P, Britter R, Gupta N. Hydrogen fuel: opportunities and barriers. J Fuel Cell Sci Technol 2009;6.

[7] IEA (International Energy Agency)/OECD (Organisation for Economic Co-operation and Development). Transport energy and CO2. Paris: IEAPublications; 2009. Available online: http://www.iea.org/publications/freepublications/publication/transport20 09.pdf (accessed on 19 January 2018).

[8] IWHUP (Integrated Waste Hydrogen Utilization Project). Dynetek hydrogen trailer system for IWHUP. Fuel Cells Bull 2007;2007(12). December 2007, Pages 8-9, ISSN 1464-2859, http://dx.doi.org/10.1016/S1464-2859(07)70426-1.

[9] Chow TT, Hand JW, Strachan PA. Building-integrated photovoltaic and thermal applications in a subtropical hotel building. Appl Thermodyn Eng 2003;23: pages 2035-49.

[10] Zogou O, Stapountzis H. Energy analysis of an improved concept of integrated PV panels in an office building in central Greece. Appl Energy 2011;88:853e66.

[11] IPPC (Integrated Pollution Prevention and Control). Reference document on best available techniques in the chlor-alkali manufacturing industry. 2000. Available online, http://www.lanuv.nrw.de/bref/Chlor\%20Alkali.pdf (accessed on 6 February 2018)
[12] Metcon Sales and Engineering. Gas scrubber system. 2015. Available online: http://www.metconeng.ca/uploads/1/5/3/5/15354030/stsscrubber.pdf (accessed 18 January 2018).

[13] National Non-Food Crops Centre. "Review of Technologies for Gasification of Biomass and Wastes, NNFCC project 09/008" (PDF). York YO10 5DG, UK

[14] The Clean and Renewable Energy Source, www.biomass.uk.com, accessed 29 December 2017 Archived 2011-09-10 at the Wayback Machine.

[15] Thermal Gasification of Biomass, International Energy Agency Task 33, www.gastechnology.org, accessed 16 December 2017 Archived 201105-09 at the Wayback Machine.

[16] Plasma gasification: Clean renewable fuel through vaporization of waste. www.waste-management-world.com. January 7, 2009. Retrieved January 9, 2018.

[17] AFSOC makes 'green' history while investing in future. US Air Force Special Operations Command. Archived from the original on 2011-0509. Retrieved January 28, 2018

[18] Göteborg Energi's biogas plant GoBiGas is now fully operational GoBiGas. gobigas.goteborgenergi.se. Retrieved January 9, 2018.

[19] Gussing Biomass Power Plant, www.clarke-energy.com, accessed 29 January, 2018

[20] Valentine KF, Temple WG, Zhang KM. Electric vehicle charging and wind power integration: coupled or decoupled electricity market resources? IEEE Power Energy Soc General Meeting 2012:1e7. http://dx.doi.org/10.1109/PESGM.2012.6344885. Berlin, Germany.

[21] Pillai JR, Huang S, Thogersen P, Moller J, Bak-Jensen B. Electric vehicles in low voltage residential grid: a Danish case study. 3rd IEEE PES Innov Smart Grid Technol Eur (ISGT Eur 2012: pages 1-7. http://dx.doi.org/10.1109/

[22] Ritte L, Mischinger S, Strunz K, Eckstein J. Modeling photovoltaic optimized charging of electric vehicles. 3rd IEEE PES Innov Smart Grid Technol Eur ISGT Eur 2012:1e8. http://dx.doi.org/10.1109/ISGTEurope.2012.6465792. Berlin, Germany.

[23] Lund H, Kempton W. Integration of renewable energy into the transport and electricity sectors through V2G. Energy Policy J 2008;36(9): pages 3578-87.

[24] Romeri M. Considering hydrogen fuel cells powertrain as power generation plant. World Electr Veh J 2010;4: pages 933-8.

[25] Larminie, J. and Dicks, A. (2003) Fuel Cell Systems Analysed, in Fuel Cell Systems Explained, Second Edition, John Wiley \& Sons, Ltd,.. West Sussex, England. doi: 10.1002/9781118878330.ch11

[26] Direct energy. What's the best temperature for my thermostat in winter? Toronto, Ontario. Available online: http://www.directenergy.com/blog/best-temperature-heater-winter/ (accessed on 3 January, 2018)

[27] Natural renewable energy laboratory (NREL). Solar resource data PVWatts calculator. Golden, Colorado. Available online: http://pvwatts.nrel.gov/pvwatts.php (accessed on 19 December, 2017)

[28] Hydrogen storage technologies. Energy efficiency and renewbale energy. US department of energy, http://www1.eere.energy.gove/hydrogenandfuelcells/storage/current_tec hnology.html; 2009 